\title{
Globalization, Conspiracy Theory, and the Shoah ${ }^{1}$
}

Ever since the beginnings of right-wing extremism, antisemitism has been one of the dominant ideological foundations that has permeated every aspect of the movement and its thought. George L. Mosse once pointed out: "Just as the right and its nationalism transformed its own myths into concrete symbols, so the enemy was not left abstract; he was embodied in Jews and parliamentarians." While for most educated strata, antisemitism became unacceptable after the Second World War and the revelations of the Holocaust, recent events have shown that antisemitism, often disguised as anti-Zionism or criticism of Israel has now begun to appear at all levels of society. It is the Jewish State which now embodies "the enemy" of humanity. For current right-wing extremists, antisemitism has taken on even greater importance since the birth of the State of Israel brought Jews into the public sphere of the Western World as equal actors. This gave antisemites a new focus. Now Jews are not only pulling strings behind the scenes, but they are playing starring roles on the world stage. A further layer of hate based on this switch has been added to ancient stereotypes. After centuries of secret manipulation, the Jew has come out of the closet, as it were, and has begun to influence, or even control, the world. Thus, the hatred of the antisemite for the Jew has perhaps even more of a force than before. This was anticipated in the last political testament of Adolf Hitler, when he wrote:

\footnotetext{
Centuries will pass away but...the hatred against those finally responsible...international Jewry and its helpers will grow.... I have also made it quite plain that, if the nations of Europe are again to be regarded as mere shares to be bought and sold by these international conspirators in money and finance, then that race, Jewry, which is the real criminal of this murderous struggle, will be saddled with the responsibility. ${ }^{3}$
}

1 This is a much revised and expanded version of the article "Antisemitismus und HolocaustLeugnung: Permanente Elemente des globalen Rechts-extremismus," that originally appeared in Globalisierter Rechts-extremismus? Die extremische Rechte in der Ara der Globaisierung, edited by Thomas Greven and Thomas Grumke (Wiesbaden, 2006). I am grateful for their permission to use it here and to Robert S. Wistrich for his editorial work on the text.

2 George L. Mosse, “Community in Nationalism, Fascism and the Radical Right," in idem, Confronting the Nation (Hanover, 1993), 44-45.

3 http://www.ess.uwe.ac.uk/documents/poltest.htm

DOI 10.1515/9783110288216.195, (cc) BY-NC-ND (c) 2017 Mark Weitzman, published by De Gruyter. This work is licensed under the Creative Commons A ttribution-NonCommercial-NoDerivs 3.0 License. 
Antisemitism, always a constant on the radical Right, was commanded by one of its most iconic figures to avenge itself against the perceived "Jewish victory" at the end of the Second World War. In this effort, the far Right continued to embrace the older, traditional forms of antisemitism, while looking for new paths and methods to reach a wider audience and overcome the stigma associated with mass murder. This is a pattern Robert Chazan described a few years ago when he wrote: "every new stage in the evolution of anti-Jewish thinking is marked by a dialectical interplay between a prior legacy of negative stereotypes and the realities of a new social context." 4

This is the case with right-wing extremism, which appears in a variety of forms, but invariably relies on traditional antisemitism as both the common thread and underlying explanation of all world problems. These varieties can include traditional neo-Nazi groups, skinheads, Holocaust denial groups, or religious extremists.

Neo-Nazism, a term which encompasses a variety of meanings, continues to be an international presence. In the United States, there is currently a period of flux within the movement, as long-time leaders like Dr. William Pierce of the National Alliance and Richard Butler of the Aryan Nation have died, and some of their possible successors like Matt Hale of the World Church of the Creator have been sentenced to long prison terms. This has left a vacuum that figures like David Duke are attempting to fill. Duke, whose group EURO (European-American Unity and Rights Organization) is one of the many that claim an international presence, has devoted much energy to positioning himself to fill the movement's leadership gap. This included spending time in Russia and the Ukraine, where he established himself sufficiently to be listed as a faculty member at a Ukrainian university. ${ }^{5}$

Duke also managed to bring together a number of prominent U.S. neo-Nazis, who met under his auspices in New Orleans in May, 2004. There they signed a document called the New Orleans Protocol, promising cooperation amongst the leadership and various factions of the movement. Along with the pledges came an aggressive and extensive assertion of antisemitism, which led one observer to write that

During the meeting, Duke singled out Jews as the source of the world's problems.... Most of conference participants' ire was directed at what they consider to be a worldwide Jewish conspiracy to destroy the white race through immigration and miscegenation. ${ }^{6}$

4 Robert Chazan, Medieval Stereotypes and Modern Antisemitism (Berkeley, 1997), 135.

5 http://www.whitecivilrights.com/flyers/Dr55.pdf

6 http://www.splcenter.org/center/splcreport/article.jsp?aid=83 
The fear of miscegenation, or "race mixing," has long been part of European Nazi and American racist groups. However, the New Orleans Protocol particularly emphasized the Jewish role in deliberately encouraging miscegenation to weaken the white race. In other words, miscegenation was viewed not only as bad in itself, but as a weapon of the international Jewish conspiracy. According to Duke, this conspiracy is based on the underlying premise of Judaism, evidenced by the fact that, in Duke's opinion "organized Jewry has pursued a successful agenda that has amassed incredible power in modern times."7 This explanation serves to explain Duke's world-view and his motivation. In his own words, he is compelled to "address what Henry Ford called the 'world's foremost problem, a problem now critical to our people's survival and freedom." ${ }^{8}$ Duke explains that his "awakening" refers to the discovery he made as a young man, of "the shared roots of both Communism and Zionism." Having made this discovery, he went on to investigate Judaism more thoroughly, and came to the discovery that what he calls "Jewish Supremacism" is at the root of all the major problems that we now face. ${ }^{10}$ Thus, for example, 9/11 was caused by Israeli actions ("Israel and its control over American foreign policy was the primary reason for this terrorism against America”). ${ }^{11}$ Globalization is also a Jewish scheme that needs to be opposed:

For the last few decades of my life I have earnestly tried to inform people that those who are the true forces behind globalism are in actuality, racial supremacists. But, they are not the so-called racial supremacists the media talks about. They are not European, African or Asian supremacists, they are Jewish supremacists. ${ }^{12}$

And, of course, no mention of the Jewish conspiracy to control the world would be complete without a reference to the classic text of antisemitic propaganda, the Protocols of the Elders of Zion. While the Protocols remain a staple of antisemitic conspiracy theorists, it is certainly no surprise to find that Duke has given them a new, updated look. ${ }^{13}$ His book, My Awakening, which alleges a Jewish plot to take

7 David Duke, “Preface," Jewish Supremacism at http://www.davidduke.com/ index. php? $=129$

8 David Duke, My Awakening, Chapter 15, at http://www.davidduke.com

9 lbid.

10 Ibid.

11 David Duke, One Year Later: The Real Causes of the 911 Attack, at http://www.davidduke.com

12 David Duke, The Lies of Globalism, at http://www.davidduke.com

13 On the history and present uses of the Protocols, along with a critical analysis and refutation of its text, see Steven L. Jacobs and Mark Weitzman, Dismantling the Big Lie: The Protocols of the Elders of Zion (New York, 2003); Andrian Kreye, "Die Falschung," Suddeutsche 
over the world, is described by one sympathetic critic as "eclipsing” the Protocols themselves. ${ }^{14}$

Duke has also embraced other themes that can help him to popularize the movement, and shore up his leadership claims. For example, he has joined those who use ecological concerns to broaden the reach of the movement. For these theorists, there is no contradiction between ecology and neo-Nazism. In fact, ecological concerns are a direct outgrowth of their National Socialist philosophies. In Duke's writings we find this spelled out directly:

I do, though, have an abiding love for our White race and the civilization and values that it created. I want my children and all my descendants to live in a free and healthy society, not a Third World hovel. I want to preserve the unique character and beauty of my people the same way that, as an ecology-minded individual, I desire the preservation of the Blue Whale or the great African Elephant." ${ }^{15}$

For Duke, it is the Jews who are the enemies of ecology. Motivated by greed, they will do anything, including exploiting nature, to turn a profit. Duke asks "do we really want the Third world to be made into economic colonies for the New World Order and the new globalism? What will this do to them, to their own cultures, to the well being of the world's ecology?" And all this to benefit "the true forces behind globalism (who) are in actuality, racial supremacists.”16

I have used Duke's writings to sketch out some of the newer themes that have become part of the current far-right discourse. These motifs, such as the emergence of anti-globalization or ecology were often seen as part of the left or liberal agenda. They have been reworked to fit into right wing extremist discourse, retooled by giving them an antisemitic cast. But these adaptations are by no means limited to ideologues like David Duke. ${ }^{17}$ The basic idea was already

Zeitung, 25-26 May 2005, presents a recent German perspective on the current status of the Protocols at the 100th anniversary of their appearance.

14 The citation is taken from a review entitled "Jewish Supremacism: A Powerful Expose of International Zionism" attributed to Edgar Johnston, Ph.D., found online at various sites, including http://www.adelaideinstitute.org/USA/019.htm This is the website of the Adelaide Institute, Australia's most notorious Holocaust denial group. Johnston attributed this statement to "prominent Jewish leaders in Russia," whom he did not identify.

15 David Duke, “America is at the crossroads," 23 Oct. 2004, http:// www.davidduke.com/ index.php? $\mathrm{p}=22$

16 David Duke, “The Lies of Globalism,” 23 Oct. 2004, http:// www.davidduke.com/index. php?p=11

17 See now the recent Southern Poverty Law Center article, "Syria/Iran: Duke, Other AntiSemites, Propagandize in Middle East," Intelligence Report (Spring 2006), http://www. splcenter.org/intel/intelreport/article.jsp?aid $=620$ 
expressed earlier by deeper and more original neo-Nazi thinkers, such as the late William Pierce in the United States, or Horst Mahler in Germany. Pierce had actually articulated such a view as far back as 1976, when he said that

\begin{abstract}
There are, in fact, several issues on which we are closer to what would ordinarily be considered the left-wing or liberal position than we are to the conservative or right-wing position. One of these issues is the ecology issue: the protection of our natural environment, the elimination of pollution, and the protection of wildlife. And there are also other issues in which we are closer to the liberals than to the conservatives, although I doubt that we agree with them completely on any issue; just as we seldom, if ever, agree completely with the right-wing on any issue. ${ }^{18}$
\end{abstract}

Thus, nearly three decades before Duke proposed a similar perspective, we can find a clear statement of this theme. And, of course, we find the same diabolical causality which invokes "the Jewish assault on all our values and institutions."19 Later in life Pierce was also using anti-globalization as a theme. In a broadcast of 5 September 1998, Pierce began by saying that "Every few months for the past several years I have used this program to warn against the policy of economic globalization." Only a few months later Pierce explicitly charged Jews with being the prime movers of globalization, when he wrote that "the process of globalization (is) being promoted by the Jews and their allies, whether international capitalists or deranged liberals." 20 The neo-Nazi extremist, Horst Mahler, also began his career on the far left as a lawyer connected with the Red Army Faction, more popularly known as the Baader-Meinhof Group in West Germany. Trained as a lawyer, Mahler defended Andreas Baader in the early 1970s, and then was jailed for participating in a violent shootout that freed him for a while. While in prison, Mahler had an epiphany and turned to the right, eventually ending up in the 1990s with the neo-Nazi NPD. Mahler left that party to join Deutsches Kolleg, which considers itself as the theoretical arm of those who hope to reconstitute a Fourth Reich. Mahler's thought contains a typically fascistic mix of left and right. For example, like both Pierce and Duke he is virulently against globalization. Mahler viewed the September 11 attacks as the first shot in a war against globalization. ${ }^{21}$

Writing ten days after the events of 9/11, Mahler said that

18 William Pierce, “Our Cause,” http://www.nationalvanguard.org/ story.php?id=3482

19 Ibid.

20 William Pierce, “Nationalism vs. the New World Order," in Free Speech (May 1998); http:// www.natvan.com/free-speech/fs985c.html

21 Jessica Stern, “The Protean Enemy," Foreign Affairs (July/August 2003). 
Globalism, already powerfully damaged by the runaway world economic crisis, will sink down upon itself, like the towers of Manhattan, under a thousand dagger strikes from Islamic fundamentalists. This collapse will finally also be the signal to the [various] peoples in the metropolises to revolt. ${ }^{22}$

According to Mahler, 9/11 meant that "Now-for the first time-a military beating has been inflicted on American ground, upon the war of extermination of the Globalists against national cultures." ${ }^{23}$ Even before 9/11, Mahler made it clear that he saw Jews as being inextricably linked to globalization. In an article dated from March 2001, he wrote

We have to find this prospect unpleasant, especially since this power hides itself behind the smoke-screen of fine-sounding words like "enlightenment," "tolerance," "emancipation," "Modernism," "human rights," "free trade," and "Globalism," and attacks and destroys nations and peoples from its place of concealment.

Mahler later made it clear that the power referred to was "the Jews" by writing that in "the present World situation, Globalism, [should be linked to] the objective existence of the Jewish Question." 24

In an interview posted on the Internet, Mahler further claimed that "there is no American war against terrorism, (but instead) we are witnessing a worldwide campaign of terror, a proxy war conducted by the USA on behalf of the Jews." He explained that:

What is generally meant by "Democracy" is actually Jewish rule, which Jewish plutocrats exercise through their control of global finance, the monetary system and the media.... I do know that the nations are going to liberate themselves from the Jewish yoke."

He even resorted to traditional Christian antisemitism by quoting John 8:44-"For ye have the devil as father, and ye wish to carry out your father's desire." 25

A recent analysis of Mahler's ideology concluded:

22 http://www.alphalink.com.au/ radnat/mahler/partfour.html

23 Mahler, "Independence day-2001," 12 Sept. 2001, http:// www.alphalink.com. au/ radnat/mahler/partthree.html

24 Mahler, "Final Solution of the Jewish Question: Discovery of God instead of Jewish Hatred," http://www.alphalink.com.au/ radnat/mahler/parttwo.html A valuable summary of antisemitism in the anti-globalization movement is in Mark Strauss, "Antiglobalism's Jewish Problem," in Foreign Policy (Nov./Dec. 2003); reprinted in Ron Rosenbaum, Those Who Forget the Past: The Question of Anti-Semitism (New York, 2004), 271-85. See also Robert S. Wistrich, A Lethal Obsession: Anti-Semitism from Antiquity to the Global Jihadi (New York, 2010).

25 http://www.stormfront.org/forum/showthread.php?p=1781479\#post1781479 


\begin{abstract}
Mahler condemned the U.S. as being responsible for this world order because of its "limitless craving for enrichment and power," which showed no consideration for the fundamentals of life of nations and destroyed economies and cultures. His anti-Americanism became intertwined with antisemitism when he targeted the American East Coast as "that web of power, money and the military." Mahler equated "imperialists" with "globalists," claiming that they governed the US which then bled other nations dry. The financial power of the American East Coast was connected, Mahler said, to the so-called cult of Jahwe, which he defined as "the cult of world power of the chosen people." Thus, the linkage was complete: solidarity with the Islamist attacks on the US, the struggle against imperialistic US power, or more precisely against Jewish financial control of the East Coast, and the fight against "globalization" and the Jews. ${ }^{26}$
\end{abstract}

These new forms of antisemitism, particularly as expressed in anti-American feeling, have taken a significant turn in the attempt by right-wing extremists to reach out to the Islamic world. Radical Islam is viewed as the only force capable of challenging the United States and the Western concepts of liberal democracy, racial or religious equality. The principle of "the enemy of my enemy is my friend" applies, as does the vicious antisemitism espoused by Horst Mahler ever since his espousal of a völkisch-racist worldview. As with the German National Socialists before the Holocaust, Mahler equates democracy with the rule of Jews who control the international financial system from which the "peoples" are seeking their national liberation.

Indeed this "liberation" has currently taken the shape of the Islamist war on the West. Again, in Mahler's words:

[T] he "September Lie," the gruesome fairy tale about Osama bin Laden's unprovoked attack on the USA, is now being challenged worldwide.... From the unmistakable victory of Washington's opponent has emerged the worldwide realization that the Jewish media monopoly represents a mortal danger for all mankind."27

Mahler makes clear that the common enemy of Islamists and right-wing extremists is Israel and also the United States (along with the West), which is its tool. This new alliance may still be utopian for most right-wing extremists, but nevertheless such attempts have been initiated, based to a large extent on mutually shared antisemitism. For example, David Duke, in a recent commentary posted on his website said that:

26 http://www.tau.ac.il/Anti-Semitism/asw2002-3/hentges.htm

27 http://www.stormfront.org/archive/t-194896Horst_Mahler_on_the_Jews.html 
the Jewish supremacist globalists seek to destroy the identity and heritage of all peoples while erecting a supra-national state of Jewish supremacy not only over the people of Palestine but over the entire planet. ${ }^{28}$

Duke has in recent years carried his message to places like Iran and Bahrain, where in 2002 he delivered lectures claiming that Israel was behind the 9/11 terrorist attacks in New York, and that the attacks were planned as a pretext to push the U.S. government into war with the Arab world. Duke's message was picked up by various Arab media sources, which helped it reach a wider audience including the Saudi Arabian Arab News, which featured a report about Duke's talks in May 2002. The website Tanzeem e-islami eagerly reproduced Duke's analysis of 9/11, entitled "The Real Evil Spirit," which blamed "the Jewish Lobby and media power...for alienat[ing] the entire Arab world" and provoking the 9/11 attacks. ${ }^{29}$

Another right-wing extremist who developed similar links is the Swiss-born financier Achmed Huber (originally Albert Friedrich Armand Huber). Huber differs from Duke in that he formally converted to Islam in 1962 in Egypt, after studying Islam in Europe with the extremist Muslim Brotherhood. Huber's neoNazi links began very early. In a 1965 interview he spoke of the influence of the Grand Mufti of Jerusalem, Haj Amin al-Husseini on his outlook. Husseini collaborated with the Nazis, met with Hitler, recruited and even organized a SS division of Bosnian Muslim volunteers. Huber at this time also spoke positively of another Nazi, Johann von Leers, who had converted to Islam, taking the name of Omar Amin. Von Leers was a fanatical antisemite in the Third Reich who became a leading figure in Gamel Abdel Nasser's propaganda machine. ${ }^{30}$ Huber was also associated with another shadowy figure, the Swiss lawyer François Genoud who consistently tried to bridge the Nazi-Islamist spectrum. Before his suicide in 1996, Genoud worked with the terrorist Palestinian Radical Front for the Liberation of Palestine. At the same time, he held the legal rights to the writings of Hitler, Martin Bormann, and Goebbels. He was also behind the legal defense of the notorious Nazi war criminal, Klaus Barbie. ${ }^{31}$ More recently, Huber allied with Horst Mahler and spoke at NPD conventions in 2000 and 2001. At the same time, his active par-

28 David Duke, "Syria's Assad speaks of Jewish media attack on identity of people," 8 June 2005 at http://www.davidduke.com/index.php?p=302

29 http://www.tanzeem.org/resources/articles/articles/david duke-the real evil spirit.htm 30 On von Leers see Robert Wistrich, Who's Who in Nazi Germany (London, 1982); Gregory Paul Wegner, Anti-Semitism and Schooling Under the Third Reich (New York, 2002) examines the impact of von Leers' propaganda on the German educational system during the Nazi era. 31 On Genoud, see David Lee Preston, “Hitler's Swiss Connection," Philadelphia Inquirer, 5 Jan. 1997. 
ticipation in Islamist activity included being one of the five members of the managing committee of Al Taqwa (Fear of God) Management, a Swiss-based financial institution believed by the United States and European governments to be supporting bin Laden by laundering money and providing other forms of assistance. In November 2001, Huber was listed by the U.S. government as number 56 among 62 organizations and individuals suspected of involvement in terrorist activities, and is not permitted to enter the United States. ${ }^{32}$ More recently, the NPD journal Deutsche Stimme published an interview with the head of the local Muslim community in its May 2006 edition. The interview presented an explanation of Islam, rather than an inflammatory attack on Jews or the United States, but it showed that the German extreme Right was ready to give a sympathetic hearing to Islam. ${ }^{33}$

The career of David Myatt represents yet another version of this extreme right-wing and Islamist axis. Myatt was a longtime member of notorious British neo-Nazi groups. Indeed he was even described by an English newspaper as the “ideological heavyweight” of Combat 18, closely identified with National Socialism. ${ }^{34}$ His 1997 pamphlet, A Practical Guide to Aryan Revolution was said to have inspired David Copeland, convicted for a series of bombings in London in 1999. A year earlier, Myatt had converted to Islam, but still continued to write neo-Nazi material that can be found on websites such as the Aryan Nation and White Revolution. Myatt, who took the Moslem name of Abdul-Aziz Ibn Myatt, continued to be a prolific writer after his conversion. As one website devoted to his work puts it "Many of these articles praise and defend Osama bin Laden, and praise and justify suicide attacks (or "martyrdom operations" as he and others call them) in Palestine, Afghanistan, and elsewhere. Myatt-using his Muslim persona-also defended the September 11 attacks and the bombings in Bali. Indeed, "Abdul Aziz" Myatt wrote one of the most detailed defenses in the English language of martyrdom operations, entitled Are Martyrdom Operations Lawful According to Quran and Sunnah? ${ }^{35}$ Myatt has also made a point of trying to amplify the connection between Islam and National Socialism. For example, a posting in his name to the neo-Nazi Aryan Nation website contains "The National-Socialist Guide to Understanding Islam" which is introduced as an attempt to find a "genuine and

32 http://www.pbs.org/newshour/updates/november01/moneylist_11-7.html

33 http://www.deutsche-stimme.de/Ausgaben2006/Sites/05-06-Gespraech.html My thanks to Thomas Grumke for this reference.

34 The Observer, 9 Feb. 2003, http://observer.guardian.co.uk/ review/story /0,6903,891761,00.html

35 J. R. Wright, "David Myatt Biographical Information: The Life and Times of David Myatt," http://www.geocities.com/davidmyatt/biog.html According to Wright, this article was even used by Hamas as a justification of some of its own terrorist activities. 
worthwhile co-operation between Muslims and people, such as National-Socialists, who accept a non-Muslim way of life and who are also fighting the dishonour which is Zionism." ${ }^{36}$ Elsewhere, Myatt speaks openly of the proposed alliance between radical Islamists and neo-Nazis. His article "Why Islam is our Ally" ends with the following conclusion:

But many, many Muslims, and some National-Socialists, have seen through the lies, the propaganda of the Zionists-for we know what is going on, in this world, and why. Muslims have and are gathering together to try and do something practical about it by taking up arms. Surely, now it is the turn of National-Socialists, who can and who should join with or aid those warriors of Islam who are fighting, in a practical way, the Zionists, who are fighting the lackeys of the Zionists, and who are fighting those governments who are doing the dirty work for their Zionist masters. ${ }^{37}$

While questions have been raised about the sincerity of Myatt's conversion, or whether he still is a Muslim, there can be no question that the underlying link for Myatt, as for others, was the hatred of Jews shared by both the extreme right wing/ neo-Nazi movement and radical Islam. Myatt also uses "Nature" to justify Nazi ideology in Darwinian terms, writing that "In essence, Aryan National-Socialism is a working in harmony with Nature to produce further evolutionary change.” 38

Over the past few years, Myatt's influence in the movement has steadily grown. Originally limited essentially to a British audience, he has received wider exposure in recent times through his conversion, after which he traveled and spoke in some Arab countries. In the West, his writings, once considered too esoteric and intellectual, can be found on popular neo-Nazi websites such as Stormfront, Aryan Nation, White Revolution, and others. His views also reflect the movement's growing interest in creating a link with radical Islam, based on the common ideology of antisemitism. For example, the Aryan Nation, a group that achieved a certain echo in the United States in the 1980s has since fallen on hard times-having lost their compound and suffered the death of their leader, Richard Butler. They now feature on the front page of their website greetings in Arabic, along with the following quotes-among others from Obergruppenführer Gottlob Berger in 1942: “...a link is created between Islam and National-Socialism on an open, honest basis. It will be directed in terms of blood and race from the North, and in the ideological-spiritual sphere from the East." Another quote comes from

36 http://www.agentofchaos.invisionzone.com/lofiversion/index.php/t696.html

37 David Myatt, Why Islam is our Ally, http://nexion3.tripod.com/islam_ally.html

38 David Myatt, “The Philosophical Foundations of Aryan Religion," http://www.stormfront. org/archive/t-98628The_Philosophical_Foundations_of_Aryan_Religion.html 
Palestinian Arab leader Haj Amin al-Husseini, speaking on Berlin radio in 1944: "Arabs! Rise as one and fight for your sacred rights. Kill the Jews wherever you find them. This pleases God, history, and religion. This saves your honor."

This recent emphasis on rebuilding a Nazi-Islamic alliance is still perceived as new and questionable by some of the more traditional members of the Aryan Nation. ${ }^{39}$ On the other hand, those in favor of this link can invoke the respect and attention that Adolf Hitler and other Nazis expressed for Islam. Clearly, in a fractured movement, the current Aryan Nations sees potential benefits in being identified with Islamist extremists. This contrasts vividly with William Pierce's insistence after 9/11 on dissociating himself from those white supremacists who admire the "testicular fortitude" of the Muslim hijackers. ${ }^{40}$

There is anonther area where Arabs and the neo-Nazis have found common ground, namely in Holocaust denial (known as the Auschwitz Lie in Germany). This has encouraged the integration of Arab antisemitism and anti-Zionism into the white supremacist program. The annual conferences of the Institute for Historical Review, the center of the Holocaust denial movement in the United States, included over the years speakers and topics that reflect an Arab perspective. The 2002 conference program featured "Arab scholar Said Arikat (who) will shed new light on the background to the dramatically unfolding events in the Middle East." ${ }^{41}$ David Irving's conferences have also featured speakers on current Middle Eastern topics from the "Arab" standpoint. ${ }^{42}$ The website of Ahmed Rami, Radio Islam, is especially notorious for the intermixing of classical antisemitism, Holocaust denial, and strident anti-Zionism in a Muslim perspective. Rami, a veteran agitator who fled Morocco and served a prison sentence for hate speech in Sweden, has an Arabic section on his website and has been featured on Al-Jazeera, the Arab news network. ${ }^{43}$

39 http://www.aryan-nations.org/ Another dissenting voice is that of veteran Alaskan neoNazi David Pringle, who has spoken out against David Duke's Middle Eastern outreach. Pringle was quoted as claiming that Duke ran the risk of becoming known as another "Hanoi Jane," referring to the controversial visit of Jane Fonda to Hanoi during the Vietnam War; http://www. splcenter.org/intel/intelreport/ article.jsp?aid=620

40 See the report from the Southern Poverty Law Center, where it is reported that "leader William Pierce recently upbraided Roper for a private comment he made-wishing that his members had 'half as much testicular fortitude' as the Sept. 11 hijackers.... Pierce called Roper's praise for the mass murderers 'ill-advised private comments.'” http://www.splcenter. org/intel/intelreport/article.jsp?aid=125

41 http://www.ihr.org/conference/14thconf/speakers.html

42 http://www.fpp.co.uk/cinc/2004/program.html

43 http://rami.tv/ 
The first real attempt to bring together prominent leaders of Holocaust denial, neo-Nazism, and Arab anti-Zionism was a non-event, although one whose proposed agenda was noteworthy. A conference scheduled for the spring of 2001 was organized by Jürgen Graf who fled Switzerland to avoid a prison sentence for hate speech and had ended up in Iran. There he found a welcoming atmosphere and support, as the Iranians officially embraced Holocaust denial. ${ }^{44}$ The proposed conference featured a roster of international neo-Nazis and Holocaust deniers including William Pierce, Horst Mahler, Roger Garaudy, and Robert Faurisson along with Arab Holocaust deniers and "representatives of Hezbollah and other radical Muslim groups." ${ }^{45}$ After a great deal of international condemnation, the conference was finally cancelled by the Lebanese government, although a watered down version was held later in Jordan without most of the major figures who had been scheduled to appear in Beirut. ${ }^{46}$ However, Iran has persisted in strenuous efforts to become an international center for Holocaust denial. In December 2005, Iran's president, Mahmoud Ahmadinejad touched off an international outcry when he labeled the Holocaust "a myth." ${ }^{37}$ Ahmadinejad was not finished, however, and called for an international conference on the topic to be held in January 2006. He even sent an individual invitation to British Prime Minister Tony Blair who had severely criticized Ahmeadinejad's earlier statement. ${ }^{48}$ The conference did eventually take place, but on a much lower level, involving the roster of familiar names from Western Holocaust denial circles along with the Iranian participants. ${ }^{49}$

44 According to the Institute of Historical Review's own website “Iran's official radio voice to the world, IRIB, has in recent years expressed support for Holocaust revisionism by broadcasting sympathetic interviews with leading negationist scholars and activists. Several interviews with IHR Director Mark Weber have been aired on the English-language service, and similar interviews have been broadcast with Ernst Zündel in German and with Ahmed Rami in Arabic. IRIB short-wave radio reaches millions in the Middle East, Europe and Asia." http:// www.ihr.org/conference/ beirutconf/background.html

45 Peter Finn, "Unlikely Allies Bound by a Common Hatred: Neo-Nazis Find They Share Views of Militant Muslim Groups on U.S., Israel," Washington Post Foreign Service, 29 April 2002.

46 Ibid.

47 http://news.bbc.co.uk/1/hi/world/middle_east/4529198.stm

48 www.dw-world.de/dw/article/0,2144,1876164,00.html

49 While veteran Holocaust deniers like Robert Faurisson and Horst Mahler were in touch with the Iranians before the conference (see "European Holocaust Deniers Involved in Iranian Holocaust Conference Plans," 27 Feb. 2006, at http://www.tau.ac.il/Anti-Semitism/updates. $\mathrm{htm}$ ), Australians Frederick Toben and Richard Krege, both of the Adelaide Institute, were the Western focal points of the conference. Their report can be found at the Adelaide Institute's website http://www.adelaideinstitute.org/Iran/conference1.htm 
A few years ago, Meir Litwak analyzed the Iranian case and its special attitudes toward the Holocaust, and drew some valuable conclusions. ${ }^{50}$ He points out that Iranian Holocaust denial "adopts the discourse and arguments of Western neo-Nazis and anti-Semites in order to grant it pseudo-scientific value." 51 He goes on to add that the validity of using these Western sources, despite Iran's general estrangement from Western intellectual discourse, is justified by the "objectivity" of these sources on Israel and the Middle East. In other words, the fact that these Western sources are "anti-Zionist" or antisemitic is all that is needed to justify their use in Iranian Holocaust denial discourse, while dismissing all other evidence as merely propaganda. The fact that Western negationist sources are exploited is covered up and wrapped in a pseudo-scholarly veneer, in order to give it greater reach and authority. This also demonstrates the intensive effort made to appeal to an international audience. Iran's goal of exporting Holocaust denial can be seen not only from the conferences that it has supported, but is also evident from the fact that a great deal of its Holocaust denial propaganda has been found in the state-owned English media. But Iran has even gone further in becoming a center of Holocaust denial. As witnessed by the words of President Ahmadinejad, the campaign has moved Holocaust denial from the murky fringes of extremism where it generally exists in the West to the center of state policy. Over the last decade and a half, through various state political and media venues, the regime in Tehran has hosted or encouraged a whole roster of Western Holocaust deniers, including some who have found refuge in Iran after being convicted of hate speech violations in the West. ${ }^{52}$ Moreover, not only is Holocaust denial at the heart of Iranian power, it is unchallenged-even if on one occasion a leader of Iran's tiny Jewish community did react to President Ahmadinejad's notorious statements. ${ }^{53}$ Where Holocaust denial in the West can be met with every form of opposition, from academic to political and legal, in Iran it is the only

50 Meir Litwak, "The Islamic Republic of Iran and the Holocaust: Anti-Semitism and AntiZionism," Journal of Israeli History 25, no. 1 (Mar. 2006): 267-84.

51 Ibid., 280.

52 The list of visitors, according to Litwak, “Islamic Republic," 277-80, includes Roger Garaudy who, after his 1998 conviction in France met with President Khatami, Supreme Leader Khamene'i, and Ahmed Rami, who had a special session of the Parliament held in his honor in 1990; Jürgen Graf and Wolfgang Frohlich were two European deniers who found asylum in Iran; and, as noted above, Iranian state radio interviewed Mark Weber (in English), Ernst Zündel (in German), and Ahmed Rami (in Arabic).

53 See, for example, "Iran: Jewish Leader Criticizes President For Holocaust Denial," Radio Free Europe, http://www.rferl.org/featuresarticle/2006/02/fb25e81f-bce9-4291-acdb-cf2c5c69fe92. html 
perspective offered by the State and its subservient media. The Iranian deniers seek to demolish the Holocaust as a means of undermining Western support for Israel-claiming that both the West and the Islamic world are victims of a massive Jewish plot reminiscent of the infamous Protocols of the Elders of Zion. ${ }^{54}$ Litwak wonders whether as younger Iranians grow restless about the government's official message, they might not grow out of Holocaust denial as one of the themes discredited by bankrupt conspiracy theories. ${ }^{55}$

The Holocaust denial movement is another example of how globalization has affected extremism. While the movement has always attempted to see itself as international in scope, both technology and politics have recently taken it further in that direction. Not by chance, Holocaust denial has been centered in California for almost three decades, in particular at the Institute for Historical Review, currently located in Newport Beach, California. ${ }^{56}$ The Institute, originally founded under the influence of Willlis Carto, a major force in American far Right extremism for decades, has in recent years been operating on its own, after Carto was ousted in a power struggle in 1994. The struggle for control of the IHR centered on a number of issues, but prominent amongst them was that Carto wanted to take the Institute's agenda into a more "racialist" direction, in other words, to expand into a wider range of topics. On the other hand, the IHR's staff, including Director Mark Weber, wanted to keep the focus on Holocaust denial. ${ }^{57}$ Without Carto's financial support, the IHR was dependent on direct mail approaches for sales and

54 For recent Iranian use of the Protocols, see Litwak, “Islamic Republic ," 272.

55 Ibid., 280-81.

56 See Deborah Lipstadt, Denying the Holocaust (New York, 1993), 50-51; also Pierre VidalNaquet's Assassins of Memory (New York, 1993) - an intriguing look at some of the discourse and cultural assertions, along with the implications of Holocaust denial, particularly in France. More recently, see Michael Shermer and Alex Grobman, Denying History: Who Says The Holocaust Never Happened and Why Do They Say It (Berkeley, 2000). There is also a substantial literature that has grown out of the David Irving trial, such as D. D. Guttenplan, The Holocaust on Trial (New York, 2001). Expert witnesses have published works reflecting their testimony, including Richard Evans, Lying About Hitler (New York, 2001) and Robert Jan van Pelt, The Case for Auschwitz: Evidence from the Irving Trial (Bloomington, Ind., 2002). Deborah Lipstadt's account is found in History on Trial (New York, 2005), while David Irving's version is found at his website, http://www.fpp.co.uk/

57 See, for example, the statement by Arthur Butz, a longtime Holocaust denier "During 1992-1993 Willis Carto sought to transform the Journal of Historical Review into a journal with a racialist political mission and editorial content." http://www.ihr.org/other/endorsements. html The page is a list of Holocaust denial luminaries who supported the ousting of Carto. 
fundraising. ${ }^{58}$ Therefore, they had to tailor their approach to a perspective that would attract the support needed for survival; and according to the IHR leadership, that theme was Holocaust denial, rather than race or politics.

Outside of being the source for a great deal of the denial writings that appear online, the California IHR website claimed 21/2 million hits in September 2005 alone. ${ }^{59}$ The first comparison I made was in November 2005, which I compared to the IHR's November 2004, page. In 2004, there were 18 stories featured and out of those 18, 16 dealt with the Holocaust, Jews, Nazis, or Israel. This was thoroughly consistent with their program, which in their own words was described as being centered on "the Holocaust issue." They also assert that "their work calls into question aspects of the orthodox Holocaust extermination story, and highlights specific Holocaust exaggerations and falsehoods...."60

However, by November 2005 the picture was different. Of the 23 stories then posted, only 14 had the themes of Holocaust and Jews. A recent look at the IHR website confirms this shift. Of the 14 stories featured, none referred to the Holocaust, almost all were concerned with current events, including the war on Hezbollah and the war in Iraq. ${ }^{61}$

The current negationist theme is clearly an attempt to build on anti-war feeling, both in the United States and abroad, and to use it to subtly attract and convince users of the argument of the site. For, if we look closely, what exactly is the message? As stated above, Jews distort reality and manipulate history for their own purposes. Thus, the distortions that are seen as connected to the way the conflicts in the Middle East are presented turn out to ultimately be just another example of Jewish conspiracy and manipulation. The title of one of the IHR articles, "The White House Cabal," confirms this-with its echoes of a secret plot to seize control of the world. In a talk in New York entitled "The Challenge of Jewish-Zionist Power in an Era of Global Struggle” (16 July 2005), IHR director Mark Weber spelled out the new focus: "no task is more urgent than breaking the stranglehold of the Jewish-Zionist grip on American political, social and cultural life." 62 The Holocaust was mentioned several times, but was far less central than the propaganda concerning Israel and the United States in 2006. Similarly, in

58 See Ted O’Keefe, “Exit the Whistleblower: My Fall from Grace from IHR," http://www.vho. org/GB/c/TOK/Whistleblower.html

59 http://www.ihr.org/news/110305ReachingNewPeople.html

60 http://www.ihr.org/main/about.shtml

61 http://www.ihr.org/ visited on 3 Aug. 2006.

62 http://www.ihr.org/other/thechallenge.html 
Australia the focus among deniers like Frederick Toben was at least temporarily on the Iraq war.

This tactical shift underlined the need to get support (especially financial), as well as to widen the base and eventually penetrate as far as possible into mainstream society. To do that it appears that significant elements of the movement have decided to embrace popular "hot-button" themes, such as anti-globalization or anger over the war in Iraq, and to use them as their points of entry, in the hope that they will help move them away from the margins of Western society. However, in adopting these themes, they have not surrendered their beliefs. Instead, they have taken the topics and undergirded them with the tropes of antisemitism that have always been at the core of their belief structure. Thus, every issue eventually comes back to the Jews, their manipulations of history and society, and their malignant influence on the world. In essence, the theme of the Protocols of the Elders of Zion remains active, only the methodology has been upgraded to reflect the new age. ${ }^{63}$ Along with controlling stock markets, Jews supposedly control multinational corporations and the banks that service them; instead of war aimed at controlling European powers, they now are behind Western (U.S.) invasions of the Middle East.

This type of material has been made much more accessible by the increased use of the Internet. Reaching about one billion people, the Internet has become the greatest propaganda tool in history, and extremists of all varieties have been quick to adapt to its use. There are currently about 5,500 extremist websites online, a jump from merely 1 in $1995 .{ }^{64}$ This has led David Duke to write about the "White Revolution and the Internet." 65 Online one can find Holocaust denial, Nazi, neo-Nazi, Ku Klux Klan, skinhead, Christian Identity, neo-pagan, and other types of antisemitism (and any other form of bigotry as well). ${ }^{66}$ The effect of the Internet cannot therefore be underestimated. It has kept these ideas current by preserving every piece of antisemitism that has ever been posted, including articles that were long forgotten; by breaking down personal inhibitions and national boundaries; by creating the opportunity to target specific groups; by providing

63 For a more detailed look at the Protocols and its themes, see Jacobs and Weitzman, Dismantling the Big Lie.

64 Digital Terrorism and Hate (Simon Wiesenthal Center, 2006).

65 For a more extensive look at antisemitism on the Internet, see Mark Weitzman, "The Internet is Our Sword: Aspects of Online Antisemitism," in Remembering for the Future: The Holocaust in an Age of Genocide (London, 2001), 1; 911-25.

66 For a short overview of many of these different groups and ideologies, see Rick Eaton and Mark Weitzman, The New Lexicon of Hate: The Changing Tactics, Language and Symbols of America's Extremists (Los Angeles, 2004). 
a source for revenue and communications; and by increasing the technological sophistication of their approach. Antisemitism and other forms of extremism have now moved into the communications mainstream. ${ }^{67}$ This mainstreaming, along with the other trends outlined above, shows how, sixty-five years after the Holocaust, antisemitism in its most radical form has come out of the closet and become an international reality that challenges us every day. Whether it be linked to globalization, ecology, or the war in Iraq, or the use of the latest technology, the contemporary discourse of antisemitism proves once more that within every new stage in the evolution of anti-Jewish thinking there is interplay between the "legacy of negative stereotypes and the realities of a new social context." ${ }^{\text {" Any }}$ response to the new manifestations of antisemitism must take into account both traditional forms of Judeophobia as well as the contemporary realities of globalization which have created a new highway for antisemitism. While antisemitism still exists in localized versions, its global impact is spread dramatically quicker and more intensively then ever before. Thus responses have to be geared toward having the same impact. Otherwise, we will be left with the sad reality that we are fighting a twenty-first century battle with twentieth century weapons, which does not bode well for the future.

67 See for example Arnold Leese's “Jewish Ritual Murder," originally published in 1938, and can now be found online on many sites, including http://www.ety.com/HRP/booksonline/jrm/ jrm_intro.htm

68 Note 3, above. 
